American Journal of Economics and Business Administration 1 (3): 225-231, 2009

ISSN 1945-5488

(C) 2009 Science Publications

\title{
Trade Externalities of Agricultural Subsidies and World Trade Organization
}

\author{
Satya Ranjan Swain \\ KIIT Law School, KIIT University, Bhubaneswar, India
}

\begin{abstract}
Problem statement: Almost every country is spending a large proportion of its income on agricultural subsidies; still the agricultural farmers of developing countries are unable to compete globally. There is increase in dependence on food imports, and a decline in food self-reliance. The aim and objectives of this study is to highlight the multiplex nature and enormity of the trade externalities of agricultural subsidies. Approach: To understand the issues and process clearly, reference has been made to GATT Agreements, WTO Agreements on Agriculture and Subsidies, policies of different countries in this regard, scholarly writings on the subject and the cases related to it. Doctrinaire methodology, which includes analytical, descriptive and comparative method, has been followed in this study. Results: Agricultural subsidies are cardinal facet of agriculture and have a major role to play in international trade. Even after separate Agreements on Agriculture and Subsidies, the World Trade Organization still failed in minimizing agricultural subsidies. Conclusion: The developing countries should unite and cooperate among themselves, which may help in advancing the cause of their own and scaling down agricultural subsidies, which has become a stumbling block to efforts to dismantle international trade barriers.
\end{abstract}

Key words: Agricultural subsidies, trade, trade externalities, WTO, Doha round

\section{INTRODUCTION}

Agricultural subsidies are considered to be the most effective mechanism for accelerating the growth of agricultural sector. It is paid, to the farmers and the agribusinesses to supplement their income, manage the supply of agricultural commodities, and influence the cost and supply of such commodities in international markets. Agricultural subsidies are designed to minimize the costs of production by providing organic fertilizers, seeds, pesticides at lower price than the market price. These grants were initially introduced as a temporary solution, as a part of the 'New Deal' policy of President Roosevelt, to alleviate the farmers and producers from the effects of the 'Great Depression' of the 1930s. Many countries followed it and started supporting the farmer community to enhance the production level. Farm subsidies were supposedly for the up gradation of farmers. But in today's globalised world agricultural subsidies has become a tool for the developed countries to maintain their supremacy.

A subsidy shall be deemed to exist if, there is a financial contribution by the government or any public body, which involves simple or potential direct transfers of funds or liabilities, government revenue that is otherwise due is foregone or not collected, providing goods or services other than general infrastructure, payments made by the government to a funding mechanism, or entrusting or directing a private body to carry out one or more of the type of functions of subsidization. But the exemption of an exported product from duties or taxes borne by the like product when destined for domestic consumption, or the remission of such duties or taxes in amounts not in excess of those which have accrued, shall not be deemed to be a subsidy.

Countries are spending a large proportion of their income on subsidies; still the agricultural farmers of developing countries are unable to compete globally. The companies cut corners in order to compete internationally. The MNCs of developed countries are in the stage of riches, while the farmers of developing countries are dying. There is increase in dependence on food imports, and a decline in food self-reliance. So, what has gone wrong in free trade, which is the modern-day religion ${ }^{[1]}$ and is embraced by both wealthy industrialized countries and government of poor countries? Why is there the tension between the exponents and the critics of agricultural subsidies? Why agricultural subsidies remained the most contentious issues in the WTO meetings and questioning the very existence of WTO in coming days? Why the developed countries are pressurizing the developing countries to reduce the subsidies? What is the controversial ground? What is that question, which is left unanswered? A humble endeavor shall be made to answer these questions throughout this study. 
Controversies: There are controversies relating to agricultural subsidies between developed and developing countries. Before the WTO, its predecessor, GATT had provided a platform for 8 trade negotiations. The Uruguay Round resulted in the creation of the WTO. In each of these rounds, the developed world dominated trade deals and the developing world were ignored $^{[2]}$. But now, the developing countries are pressurizing the developed countries to change their agricultural policies. A group of 20 nations (G-20) is actively pursuing the developing nations cause regarding subsidies. The key demand is the reduction of any type of farm subsidies.

While subsidies give an unfair advantage to the farmers in the developed countries to sell their goods at a lower price, the countries in South do not have enough resources to subsidize their farmers in a similar fashion. Their main protection is using tariffs to keep out products from other countries. But the use of tariffs is under attack at the WTO as this is against the trade ethics.

The United States recently proposed to ban many types of subsidies, which if adopted, will have grave implications on developing countries. The developed countries, which are popularly referred as "the champions of free trade", believe in opening the global market and imposition of a few restrictions on trade. On the other hand the developing countries believe in concentrating on the welfare of the domestic economy by limiting the open-market policy. The developing countries have opposed the proposal, saying it would halt development in their countries by affecting growth or even the survival of their firms. They will lose the ability to use these subsidies which are now permitted. The developed countries have also been making use of these subsidies, particularly when they were at their development phase. Now their companies have become giant multinationals. So, they want to prohibit these practices, in order to prevent the entry of new competitors.

Moreover, US wants to exempt the agricultural sector from the banning of subsidy. In agriculture, US is providing massive domestic subsidies and also wants to continue these subsidies. Now US is even refusing to discuss on it. The proposal appears to be a monopolistic attempt by the existing producers to squeeze out competition ${ }^{[3]}$. The double standards in the US proposal are causing the developing countries to call "Foul!" In the Doha Round negotiations, the US proposal of banning subsidies was taken up. The US wanted the countries to notify the WTO of the details of government or public-sector ownership of an enterprise. This is to indirectly track down any practice of the prohibited subsidies.

In particular, US and EU have given huge supports to their farmers, and the surplus generated by this has been disposed of in the international market. They are dumping grain by selling at prices far below the cost of production, which is unfair to developing countries. The US indicated its willingness to reduce its "tradedistorting support" by $53 \%$ provided the EU and Japan reduced theirs by 75 and $53 \%$ respectively. Similarly EU will reduce its support by $70 \%$, provided some of its conditions are $\operatorname{met}^{[4]}$. The developing countries object the US farm subsidies as they unfairly block out foreign competition. Hulse ${ }^{[5]}$, food technology and development expert and president, Siemen-Hulse International Development Associates, Ottawa, Canada, expressed that India should take a much more active role in opposing this at UN and other platforms. The countries also wanted developed countries to implement duty free and quota free treatment to least developed countries $^{[6]}$. The counter argument holds that US farm subsidies are necessary to prop up the US farm industry.

In food-exporting countries, agricultural subsidies have been designed to increase farm income, either by raising the long-term level of prices above free-market levels or by providing direct payments to farmers. The sale of agricultural products to developing nations at below market prices has often had a devastating effect on the ability of farmers in those nations to prosper, and the continuation of such subsidies has become a stumbling block in efforts to dismantle international trade barriers ${ }^{[7]}$. Subsidy programs also exacerbate price swings in world markets and disturb the development of sustainable export sectors.

In order to maintain the price level in domestic economy and to encourage disposal of surplus to the outside market, the developed countries provide huge export subsidy. The developed countries subsidize farmers while developing countries tax farmers. Agricultural subsidies in developed countries reduce world prices, and thus the incomes of the farmers of other countries declines. In 1993, an agreement was reached requiring developed countries to reduce agricultural subsidies. Though there are many loopholes in the agreement, it was a worthy attempt for the reductions of subsidies. Agricultural subsidies in developed countries seem good to importers of food ${ }^{[8]}$. But it is evil for the developing countries, which is exporting. 
Subsidies in the developed countries: There is a trendy misconception that agricultural subsidies are given in order to stabilize the incomes of poor farmers. But the government in many developed countries takes advantage of that misunderstanding. If that were the case, the federal government of US could bring the income of every full-time farmer in America up to $185 \%$ of the federal poverty level for just $\$ 4$ billion per year $^{[9]}$. But, US spends nearly $\$ 20$ billion annually ${ }^{[10]}$.

The eligibility for farm subsidies is determined not by income or poverty standards but by the crop that they grow. The producers of wheat, cotton, and rice, which happen to be the nation's most profitable crops, receive more than $90 \%$ of all farm subsidies, while others are completely shut out of farm subsidy programs. Since 1991, subsidies for large farms have nearly tripled, but there have been no increases in subsidies for small farms, in $\mathrm{US}^{[11]}$ Large farms are using subsidies to purchase small farms and consolidate the agriculture industry. As they buy up smaller farms, not only are these large farms able to capitalize further on economies of scale and become more profitable, but they also become eligible for even more subsidies, which they can use to buy even more small farms. So, agricultural subsidies are largely seen as corporate welfare program rather than a common man program.

Impact of agricultural countries on the developing countries: An Indian experience: The unjustified use of farm subsidies by the developed countries is creating havoc for millions of poor farmers around the globe. The growing volumes of subsidies are the new instruments for projecting a pro-poor image. Indirectly the developed countries are forcing the farmers of the developing countries to abandon farming and migrate to the urban-centers.

Let's now concentrate on the impact of subsidies in India. American wheat is available in Chennai (Capital of Tamil Nadu in South India) at a landing price much lower than that of the home grown grain. Food processing units in south India therefore find it economical to import wheat than to transport it from northern parts of the country. The result is that while the wheat surplus in the north-western parts of the country rots in the open, traders and food processing industry relies on imports. Wheat growers in the north suffer, and many of them have gone bankrupt.

Developed countries can afford farm subsidies as their agricultural sector constitutes a paltry2- 4\% of their economy. To subsidies agriculture to the extent of $50 \%$, developed countries need to spend around a meager $1-2 \%$ of their total GDP whereas in developing countries like India, where more than $60 \%$ of population are Developed countries can afford farm subsidies as their agricultural sector constitutes a paltry 2 to $4 \%$ of their economy. To subsidies agriculture to the extent of $50 \%$, developed countries need to spend around a meager $1 \%-2 \%$ of their total GDP whereas in developing countries like India, where more than $60 \%$ of population are engaged in agriculture, the spending needed is $13-14 \%$ of the $\operatorname{GDP}^{[12]}$.

Agriculture under the GATT: The primary focus of the GATT was the reduction of tariffs and other barriers to trade. Article XI: 2 is the only provision, which specifically refer to agriculture while Article XVI refers to primary commodities, which indirectly include agricultural products. The difference between Article 25 of the Havana Charter, the charter of the defunct International Trade Organization to reduce anti competitive business practice, and GATT Article XVI on the use of subsidies could not be reconciled until the 1955 GATT Review Session, which damaged the credibility of the GATT ${ }^{[13]}$.

The GATT prohibited export subsidies on manufactured goods (Article XVI: 4 of GATT). But it didn't restrict agricultural export subsidies as long as the country providing the subsidies did not thereby gain more than an equitable share of world export trade in the subsidized product (Article XVI: 3 of GATT). So, the GATT contracting parties have rarely succeeded in challenging agricultural export subsidies under this provision. Under this circumstance the GATT dispute resolution panels have been very reluctant in finding that the export subsidies of one contracting party have distorted the export of the complaining parties. Moreover the GATT Article XVI: 3 has not been an effective mechanism in limiting export subsidies.

The GATT did not directly address the use of domestic agricultural subsidies ${ }^{[14]}$. However, there are two GATT provisions that may apply to domestic agricultural subsidies. First, GATT contains a general obligation to report all subsidies that operate to increase exports or decrease imports and to consult, on request, with other GATT members "on the possibility of limiting the subsidization". This provision may apply to domestic subsidies to the extent that these subsidies lower the price of domestically produced goods and thereby enable domestically produced goods to undercut the price of imports. Second, GATT dispute resolution panels have concluded that the use of domestic subsidies to offset the expected benefits of a tariff reduction on imports may constitute nullification and impairment of GATT benefits pursuant to GATT Article XXIII. 
Agricultural policy in developing countries under the GATT was characterized by a transfer of income from rural farmers to urban dwellers. Policies that transferred income from farmers to consumers included taxes on agricultural exports, subsidies on agricultural imports, and the payment to farmers of less than world market prices by state purchasing agencies.

Though GATT was a worthy attempt to reduce subsidies but it failed for many reasons. When GATT was established, no formal recognition existed between the contracting parties. All rights and obligations were applied uniformly to all, while 11 out of 23 of the original GATT members were "developing country", who participated on the equal game field, jeopardizing their economies. The GATT dispute settlement system is, at the margin and more responsive to the interests of the developed countries. These underlying imperfections led to the Special and Differential Treatments (SDT) provisions in the WTO during the Uruguay round, which led many countries to question the "principles and objectives of the SDT, utilization, graduation, and universal vs. differentiated treatment approaches". Post-Uruguay round the SDT provisions in the WTO comprise a set of conditions that all countries universally must maintain towards developing countries: to increase trade opportunities, to safeguard developing countries' interests, to offer flexibility of commitments under the WTO rules, allow transitional time periods, and provide technical assistance to the Lower Developed Countries (LDC). But the developing countries have failed to live up to their commitments ${ }^{[15]}$.

The GATT was not hard on the developed countries. The only obligation imposed on US was to submit periodic reports on the application of the waiver, and these simply served to underline the extent of the damage that had been inflicted on the GATT.

The agreement on agriculture: The WTO's Agreement on Agriculture was a significant step towards fairer competition and a less distorted sector ${ }^{[16]}$. The main aim of the Agreement is to encourage fair and market oriented trade in agriculture by removing trade distortions resulting from differential levels of input subsidies, price and market support, export subsidy and other kinds of trade distorting support ${ }^{[17]}$. Strengthening rules to improve predictability and stability for importing and exporting countries, making specific commitments on market access, taking fully into account the particular needs and conditions of developing countries by providing for a greater improvement of opportunities and terms of access for agricultural products are the focal point ${ }^{[18]}$. It was anticipated that implementation of the Agreement would raise the international prices and would improve export prospects for developing countries. But the problem in this is that it allows US and EU to continue to subsidize agricultural production and to dump surpluses on world markets at artificially depressed prices while requiring developing countries to open up their markets to ruinous and unfair competition from industrialized country producers. The biggest beneficiary of the Agreement was US. In fact, almost $70 \%$ of US domestic support granted in 2001 was designated as non-trade-distorting.

The domestic agricultural policies were major factors in restraining the growth of international agricultural trade. The Agreement reduced the Total Aggregate Measurement of Support by $20 \%$ for developed countries, $13.3 \%$ for developing countries, and $0 \%$ for least-developed countries during the implementation period. The Agreement reduced the values of mainly direct export subsidies to $36 \%$ below 1986-90 base period level over the six-year implementation period, and the quantity of subsidized exports by $21 \%$ over the same period. The reduction in values for developing countries will be two-thirds of the reduction for developed countries and will be carried out over 10 years period. The least developed countries are exempted.

The Agreement failed in its objectives but the principal achievement of the Agreement was to create a framework for the further systematic liberalization of trade in agricultural products.

The agreement on subsidies: The WTO's Agreement on Subsidies and Countervailing Measures disciplines the use of subsidies, and regulates the actions that the countries can take to counter the effects of subsidies. Under this Agreement, a country can use the WTO's dispute settlement procedure to seek the withdrawal of the subsidy or the removal of its adverse effects or a country can launch its own investigation and ultimately charge "countervailing duty" on subsidized imports ${ }^{[19]}$.

Doha round and agricultural subsidies: Agriculture was one of the central issues in the Doha Development Agenda ${ }^{[20]}$. The main objective of this round, from the beginning was to straighten out some of the kinks in agricultural trade. This activity, which accounts for only $8 \%$ of world merchandise trade, is the most heavily distorted by misbegotten policies ${ }^{[21]}$. The goals of US were substantial reduction of trade-distorting domestic support; elimination of export subsidies, and improved market access ${ }^{[22]}$. It is, therefore, in agriculture that an agreement could do the most good. But it was also in agriculture that the agreement came 
unstuck. On July 29th, after nine days of negotiations, the Doha round (2006) stalled. The reason was that US refused to cut subsidies to a level where other countries' non-subsidized exports would have been competitive. The US continued to argue for big cuts in farm import tariffs to open up markets for its farmers. It asked the EU and the developing countries to make a more generous offer for reducing trade-distorting domestic support.

But this demand was rejected by the EU, Japan and India, which said America had first to go further in offering to cut agricultural subsidies ${ }^{[23]}$. Brazil has emphasized reductions in trade-distorting domestic subsidies, especially by US while India insisted on a large number of special products that would not be exposed to wider market opening.

This created a dead lock on agricultural tariffs and subsidies. Pascal Lamy, the Director-General of the WTO said, "Members simply could not able to bridge their differences" ${ }^{[24]}$. Developed countries failed to agree with developing nations on terms of access to each others' markets. While the US and the EU wanted greater access to provide services to fast-growing emerging countries, developing countries wanted greater access for their agricultural products in EU and US. So, the Doha round of negotiations held during July 23-29, 2008 broke down and was suspended for indefinite period. The US and some EU members blamed India for this thaw in global trade relations ${ }^{[25]}$. On the other hand India accused the US of putting the livelihoods of a billion of the world's poorest people against "commercial interests". India also made it clear that its position is supported by 100 other countries, representing a billion subsistence farmers ${ }^{[26]}$.

It is not that no agreements have been accomplished; rather a number of agreements had been reached, but they were contingent on a panoptic agreement in the single undertaking -"nothing is agreed until everything is agreed".

Developed countries' stand on subsidies programs: US, the so called "architect of the trading system and the custodian of liberalism" insisted that despite the general ban on quantitative restrictions contained in the Article XI, a provision be included that will permit the retention of quantitative import restrictions when necessary to enforce domestic agricultural programs. Article XI: 2(c) legalized the retention of Section 22 of the US Agricultural Adjustment Act of 1933, which allowed quota to be imposed whenever imports threatened to impair the domestic support programs. This Act was amended and the US requested a waiver to eliminate any possible inconsistency. The amendment sought to assert the primacy of the US domestic program over the GATT, especially in the import restrictions. Governments intervene in the agricultural sector to provide adequate food, achieve self sufficiency and promote rural welfare. Rich countries do it by providing direct financial support to their producers. So, US have to give subsidies to ensure self reliance in food. Secondly, they want to ensure that their soil resource is just as productive as it was hundred years ago. So, it is an investment in society's long-run benefit. Thirdly, they take international markets is not at all farmers competing against farmer. Agricultural markets in the US tend to be fairly open. The average tariff faced by countries trying to land agricultural products in US is around $12 \%$, while the average tariff faced by US farmers is around $62 \%$. US farmers work in very different regulatory environs than exists in several other countries. So, subsidies program is just a compensation to help the domestic farmers in the playing field. Not only farmers, even they provide protection to other sectors of the economy when they face unfair competition. So, why should agriculture be any different ${ }^{[27]}$ ?

The case of Brazil-US farm subsidies: Brazil had launched a WTO case against the US farm support programs. Brazil alleges that since 1999, the US has often exceeded its WTO spending limits for heavily trade-distorting agricultural subsidies. It is also targeting some tax breaks and export credit guarantees, arguing that they are tantamount to prohibited subsidies. Brazil further claims that Washington surpassed its $\$ 19.1$ billion entitlement for such 'amber box' spending in 2000, 2001, 2002, 2004, and 2005, as well as the prior $\$ 19.8$ billion ceiling in 1999 . The complaint highlights the US failure to notify the WTO of its subsidy expenditures since 2001, before spending under the lavish 2002 farm bill came into effect. Nevertheless, "available public information indicates that the domestic support, which the US provided exceeded its commitment levels" in 2002, 2004, and 2005, thus violating multilateral trade rules. From 1999 to 2001, Brazil argued that the US had improperly notified amounts within its spending limits. On the other hand, US officials dismissed Brazil's claims, arguing that subsidies remained within legal limits ${ }^{[28]}$.

The Canadian and Brazilian cases are similar in concern $^{[29]}$. Brazil's request did not mention the issue of whether US farm subsidies were distorting world prices to the detriment of producers elsewhere. Tradedistorting subsidies with such adverse effects are not permitted under the WTO Agreement on Subsidies. Oxfam, a development campaign group said the US 
subsidies were pushing down global prices for the commodities $^{[30]}$. "The dispute resolving panel of WTO ruled that the US remained in violation of world trade rules even after it repealed its 'Step 2' payment to cotton mills and exporters in August 2006"[31]. The threemember WTO compliance panel said, "The US has failed to comply". So, Brazil has reserved the right to impose annual sanctions of as much as $\$ 4$ billion on the US but would probably seek less in retaliatory measures because the US has removed some of the offending subsidies $^{[32]}$.

Similarly there are many cases against US and by US. Apart from this the other country to share with US is EU, Brazil, Australia, India and Canada.

\section{CONCLUSION}

The Doha negotiation was suspended when US EU, Brazil, India, Australia, and Japan; popularly known as the G-6, reached an impasse over specific methods to achieve the broad aims of the round for agricultural trade. Mr. Kamal Nath, India's Commerce Minister, walked out of WTO meet in Geneva to let the developed countries know that India and other developing countries are no longer a push over. But walking out is not a solution.

The developed countries had many a times tried to divide developing countries by offering individual negotiations. They also want to break the solidarity between Brazil, Mexico, India and other developing countries by portraying that, the economic environs of the countries differ and as a result of which the developed countries, particularly US got maximum benefits in the past agreements and negotiations. So, the developing countries should unite and cooperate among themselves, which may help in advancing the cause of their own, scaling down the agricultural subsidies and dilute the negative side-effects.

\section{REFERENCES}

1. Watkins, K., 1996. Free trade and farm fallacies: From the Uruguay round to the world food summit. http://www.accessmylibrary.com/article-1G119313816/free-trade-and-farm.html

2. Sud, H., 2006. World Trade Organization WTO and India.

http://www.saag.org/common/uploaded_files/paper 1879.html

3. Khor, M., 2007. Storm over WTO proposal to ban subsidies. http://www.twnside.org.sg/title2/gtrends/gtrends15 9.htm
4. Dhar, B., 2002. Pressure of farm politics. The Frontline.

http://www.flonnet.com/f12224/stories/2005120200 3403100.htm

5. Hulse, J.H., 2002. India should lead the campaign against farm subsidies in the West. The Frontline, http://www.hinduonnet.com/fline/fl1926/stories/20 030103002208900.htm

6. The Hindu, 2006. India: Eliminate farm subsidies. http://www.hindu.com/2006/07/18/stories/2006071 808351200.htm

7. questia, 2004. Agricultural policies of the United States. http://www.questia.com/library/politicsand-government/agricultural-policy-u-s.jsp

8. Mshomba, R., 2002. How Northern subsidies hurt Africa.

http://www.un.org/ecosocdev/geninfo/afrec/vol16n o2/162agric.htm

9. Elortondo, L., P.J. Blokland and J.K. White, 2005. Globalization, Agriculture and the USA. Teaching and Learning Paper, Food and Resource Economics Department, IRREC, University of Florida. http://irrec.ifas.ufl.edu/files/student_work/05_5_\% 20Elortondo.pdf

10. Riedl, B.M., 2002. Still at the federal trough: Farm subsidies for the rich and famous shattered records in 2001 .

http://www.heritage.org/Research/Agriculture/BG1 542.cfm\#pgfId=1011209

11. Farm Programs: Information on Recipients of Federal Payments, 2001. US General Accounting Office Report to the Chairman, Committee n Agriculture, Nutrition and Forestry, US Senate. http://www.gao.gov/new.items/d01606.pdf

12. Singh, G.P., 2008. Farm subsidies: What's your take?

http://www.merinews.com/catFull.jsp?articleID=131328

13. Macrory, P.F.J., A.E. Appleton and M.G. Plummer, 2005. The World Trade Organization: Legal, Economic and Political Analysis. 1st Edn., Springer Publication, ISBN: 978-0-387-22685-9, pp: 89.

14. Gonzalez, C.G., 2009. Institutionalizing inequality: The WTO agreement on agriculture, food security, and developing countries. Social Science Research Network. http://papers.ssrn.com/sol3/Data_Integrity_Notice. cfm?abid $=987945$

15. Rabimov, S.R., 2004. Why developing countries of the WTO need special and differential treatments? Social Science Research Network. http://papers.ssrn.com/sol3/papers.cfm?abstract_id $=637761$ 
16. World Trade Organization, 2001. Agricultural. http://www.wto.org/english/tratop_e/agric_e/agric_ e.htm

17. Chand, R., 2001. Subsidies and support in world agriculture: Is WTO providing level playing field? http://www.ncap.res.in/upload_files/policy_brief/p b14/pb14.htm

18. World Trade Organization Legal Texts, 2001. Uruguay round agreement, agreement on agriculture. http://www.oecd.org/dataoecd/50/55/1912374.pdf

19. World Trade Organization, 2003. Subsidies and countervailing measures.

http://www.unctad.org/en/docs/edmmisc232add15 _en.pdf

20. Hanrahan, C.E. and R. Schnepf, 2007. WTO Doha Round: The Agricultural Negotiations. CRS Report.

http://www.nationalaglawcenter.org/assets/crs/RL3 3144.pdf

21. The Economist, 2008. The Doha round...and round....and round.

http://www.economist.com/businessfinance/display story.cfm?story_id=11848592

22. Fergusson, I.F., 2008. WTO Doha round: The agricultural negotiations. CRS Report. http://www.nationalaglawcenter.org/assets/crs/RL3 2060.pdf

23. Beattie, A., 2006. US blamed as trade talks end in acrimony. Financial Times. http://www.ft.com/cms/s/0/dfa460d0-1afd-11dbb164-0000779e2340.html?nclick_check=1

24. BBC NEWS, 2008. World trade talks end in collapse. http://news.bbc.co.uk/2/hi/business/7531099.stm

25. Blakely, R., 2008. India blamed for Doha collapse by trying to protect poor farmers. http://business.timesonline.co.uk/tol/business/econ omics/article4427725.ece
26. Stewart, H., 2008. Doha: India accuses US of sacrificing world's poor at trade talks. http://www.guardian.co.uk/world/2008/jul/31/wto.i ndia

27. Young, B., 2007. Should the United States Cut Its Farm Subsidies? http://www.cfr.org/publication/13147/

28. World Trade Organization, 2007. United StatesSubsidies on upland Cotton, Dispute http://www.dfat.gov.au/trade/negotiations/disputes/ downloads/267_cotton_oralstatement.pdf

29. Good, K., 207. Canada requests new WTO panel on US agricultural subsidies. http://www.farmpolicy.com/?p=537

30. ICTSD., 2007. Brazil launches WTO case against US farm subsidies. http://ictsd.net/i/news/bridgesweekly/6534/

31. USDA., 205. USDA proposes legislative changes to cotton and export credit programs to comply with WTO findings. http://www.usda.gov/wps/portal/!ut/p/_s.7_0_A/7_ $0 \_1 \mathrm{RD}$ ?printable $=$ true $\&$ co $\% 20$ ntentidonly $=$ true $\& \mathrm{c}$ ontentid=2005/07/0242.xml

32. Los Angles Times, 2007. Cotton subsidy is ruled illegal. http://articles.latimes.com/2007/dec/19/business/ficotton19 